\title{
A Trabilious Administration of the Districts in Gimbî 1941 to 1991
}

\author{
Dereje Biru Adal* \\ Department of History and Heritage Management, Bule Hora University, Oromiya, Ethiopia
}

Submission: October 05, 2017; Published: December 22, 2017

*Corresponding author: Dereje Biru Adal, Department of History and Heritage Management, Bule Hora University, Oromiya, Ethiopia, Email: derejebiru66@gmail.com

\begin{abstract}
The people of the Oromo have a long life span of administration under Gada system in the Oromia in general and Gimbi Districts in particular. The wonderful and examplenary of the Oromo declined by the cooperation of the central government and petty regional rulers. In addition, the contribution of the abba lafa, missilane woreda and zonal level dispersed Gada practice. The heavy hand of the emperor Hailesillase evaporated by the conglomeration of the peasants, students, military, drivers and teachers. The transitional period brought land to the land tiller under the Derg's regime. The Derg exacerbated farmers of Gimbi saying zemecha, peasants farm qudad land to the central government, and forcefully ordered farmers to come at the same place. There were many forces which became sabotage for the Derg as a county level. As a Gimbi Districts, Oromo Liberation Front became a headache for the Derg. While qaruutee, soonii and jajabee are braches of their mutiny; muraasaa, saglii, buttaa, cibraa, birgeedii and kutaa waraanaa were the structure of the Oromo liberation front of the period. This research is conducted though qualitative method. The research is writing down through deep reading of primary and secondary sources as well as comparing it with Oral tradition
\end{abstract}

\section{Introduction}

The Oromõ had a peculiar system of rules and regulations that operated for a long period of time called the Gadã system. It encompasses different points: rules and regulations, time interval of each Gadã grades and so on [1] (Giday) It served the Oromõ society as an administrative law. Starting from the time of empire building in Ethiopia especially during the reign of emperor of Menilek, the practice of Gadã system declined dramatically. This was because, when emperor Menilek crossed over to Wallagã by having peaceful submission as well as forceful subjugation of the people. West Wallagã began to be ruled under the central government of Ethiopia. Menilek's domination brought the new challenges to the free exercise of the Gadã system in Wallagã in general and West Wallagã in particular.

\section{Methodology}

The long run administration system in Ghimbi districts is an attractive topic. So far to construct the history of Ghimbi districts, both primary and secondary sources are crucial. While primary sources are oral traditions and archival sources, the secondary sources are published and unpublished works. In order to get the reality of sources, cross-checking published materials and as well as unpublished ones is vital. Implies, Oral source is also important for this research.

\section{Result and Discussion}

\section{Administration of the Districts in Gimbî 1941 to 1991}

This new political system continued during Lij Iyasu as well as the diarchy. Since written account on the political history of the Oromõ of West Wallãgã (Districts in Gimbî) is scarce, this study tries to fill in this gap. As soon as new administration system came and undermined the former Gadã administration system, some people began to support the new comers so as to gain new advantages from the new political leader [2,3]. This study treats political history of the Oromõ of West Wallagã from liberation to 1991.

The Italian occupation of Ethiopia collapsed by the British involvement in the country. The British wanted to eradicate the Italian citizens from Ethiopia. This was because, Italy sided with Germany against the British and the Franch during WWII. Therefore, emperor Hailesillassie returned from abroad and began to rule Ethiopia. The emperor began to administer by dividing the country into provinces, awurajjãs as well as waradãs [4]. Ethiopia had fourteen administrative regions up until the dawn fall of the Darg. Oromo was one among them. Wallagã was divided into six awurajjãs. These were Naqamte, Gimbî Q llam, Shãmbu, Arjõ, and Asõsa [5]. All these awurajjãs had their own 
districts. Gimbi Awurajjã also had its own districts or waradas like Najjõ,Yũbdõ, Nõle-Kãbbã, , Gimbî, Mana-Sibũ and whereas

Lãlõ-Asãbi, Hãru and others are among the recent ones Figure 1.

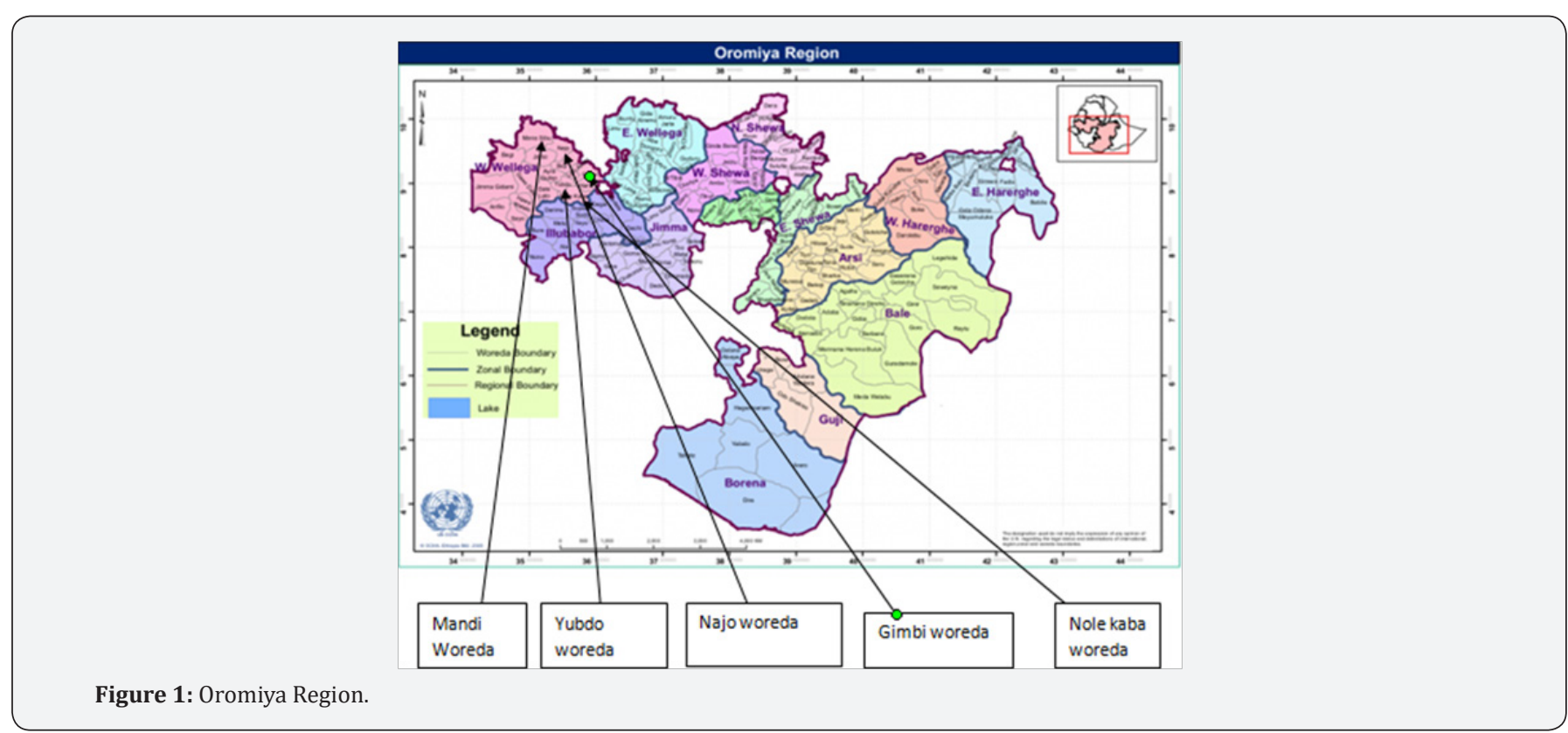

The governor of each province, awurajjã and waradã collected taxes and paid to the central government [6]. The land tax up until 1942 was in kind. It "requires farmers to pay taxes, in the official currency instead of in kind." [7] In addition to this, "education tax was introduced in 1947 and health tax was later added." [7] "Land grant continued and the land was registered as private property which could be bought and sold." [5] Later on the payment was determined by the amount of land holding of the peasants [8]. "The land lords sold the Coffee and grain collected from tenants to merchants in the small towns of West Wallagã " [5] "The Italians gave back the land of the crown, church and naftañãs to the Oromõ peasants and abandoned taxation"[9]. The land that was given to the Oromõ by the Italians during their occupation, was taken by force by the emperor of Ethiopia in the post liberation. The social, economic and political systems of the Oromõ were destroyed by Emperor Hailesillassie.

Abba korõ had a strong authority over the peasants of Ethiopia. Abbã korõ was nominated depending on his braveness, administrative skills and who could traveled long distance. Korõ was nominated by the families of Kumsã Moroda. The son of Kumsã-"Moroda Bakare gained supremacy over Gimbî, Hãru, Arjõ, Najjõ, Bãbbõ-Gambel and Mana-Sibũ" [10]. Abbã korõ went to Naqamtee traveled long distances. He must serve the administrative of the province. Korõ was elected on each clan. One big clan might have two korõs. Below abbã korõ chika shum existed. He settled peace and security guided by abbã korõ. Two small clans brought together and nominated one korõ. Korõ was administered by atibiya dãñã. It was nominated upon the korõs in 1945 .

One kabale had one atibiya dãñã. While atibiya dãñã ordered korõ, the korõ ordered peasants. Abbã korõ mobilized society against the enemy. "Abbã Korõ collected taxes and could order all peasants within their area of administration to work and contribute money for varies official purposes"[5]. The amount of tax the peasant paid was determined by the koro. Taxation of land depended on its virginity. Taxation of lamlam, taflam and taf land were 40-50.00, 25.00. And 15[11] birr respectively. Gutema says:

...various taxes: tax on honey (gibira damma),tax on tobacco (gibira

tambo), tax on cotton(gibira jirbi) and tax on each house (gibira

mesha mana). Half of Maria Theresa thaller for honey tax ,1/4 of $a$

thaler for tax on tobacco, half of tax on cotton and one thaller for tax

$$
\text { on each house [ were levied[11] }
$$

Thuis implies that, the government had other forms of land holding system like:

\section{Gabbãr Maret-individually owned land whose properties paid}

taxes directly to the government. Sissõ Maret- tracts of land owned by the korõs and cultivated by tenants who gave the latter a

3rd of crops.Sãmõn Maret- piece of land owned by the Church and

Worked either by the priest or gabbars.Madareya Maret- land 


\section{Global Journal of Archaeology \& Anthropology}

held

on temporal basis by persons who were important personalities of

hand in some way distinguished themselves in government services [12].

Peasants asked permission from the governor to construct corrugated houses. The governor received a piece of land he wanted. According to my informants the governor accused him 27 times to take over his land. These accusations had the same witnesses who gave false testimony at the court.

Developmental projects like construction of bridges, roads, and kabale houses were ordered by the abbã korõ (duke). Atibiya dãñã also served as a judge. The people presented their cases to him. He could see cases worth up to twenty five birr. He was authorized to punish them up to fifteen birr. The amount of land held by the Atibiya dana depended on the number of clans. For example, atibiya dãnyã of Hõma had 42 kalad. In another case, it might have up to eighty kalad. Hõma had six clans: Gabãnõ, Himbirarõ, Warra Molu, Warre, Satõ and Gãkkõ. Their governors were: Abigar Shuke, Mangashã Bãlcha, Mangashã Dh ressa, Disãsa Suge, Agabãsa Bõdh , and Daras Dãnõ respectively.This means that, Mana- Sibu Warada had more than fifteen clans. These were Bari, Bacharra, Bãfano, Igu, Giddã, Muk, Sinichõ, Lemmu, Talãnsõ, Kur Gambõ, Wãjati, Harawe, Bãbõ, But, Buyama and so on. The governors were Mokonin Jõte Tufa, Bayãna Kurõ Farõ, Jirãta Dakkõ Tolina, Abate Galata Fayisã, Tõbõ dibãba sarka, Tolasã Tuchõ Odã, Biyana Tokon Sõri, Ababa Jõte Tufa, Namara Gamada Jãmmõ, Guma Wallagã Jãnnõ, Bayisa Cibsa Gombõ, Dhuferã Gaga Buba, Lamu Waltaji Sõlan, Likãsa Hõma Kãnkure, Bõka Karrõ Girmõsa, Gutatã Jãrra Dibãba respectively. Hereditary power transmission was common for all governors. The governor of (bari) Mokonin Jõte Tufa received from his father Jõte Tufa. This situation was common for all other governors. Axibiya dãnyã was administered by misilane. Misilane was nominated by provincial administrator. Gimbî Awurajjã administrators were kañazhmachYamane Kuamsã, Tãdase Mãrqõs, kañazhmach Kãsa Tachãne, kañazhmach Hayilu B ra, Masfin Wold Mãriyãm for three month and Hayilu Wadãjõ. When Mangistu HayilMãriyãm took power, Hayilu Wãdajõ was Gimbî Awurajjã administrator.

Malkaña was a leader of the peasant during the preItalian occupation of Ethiopia. Malkaña was terminated by the Italians. The Italians gave land to the owner (farmers) [13-14]. The farmers of Districts in Gimbî began to administer their land during the Italian occupation. The malkaña of Hõma Sîba were Bongãs Sorî, Whereas Ejeta Rõrõ was a malkaña of Sîba. Mõti Damise was Sîba atibiyadãñã. The Nõle Kãbbã Waradã atibiya dãñã were: Rabi Sõlan, Asfawu Mokonnin, Kabad Firisa, kañãzhmãchAsfawu Bidiru, Adãmu Balay and so on. The first Gimbî Warada Atibiya dãñã were Hunde Amanu and Tãdase Nagari. Qaññãzmãch Rabi Sõlõn was the first person who joined the parliament among the atibiya dãñã of Nole Kãbbã. There were two elections in Wallagã during the imperial period. The first election station consisted: of Hãru, Yũbdõ, LãlõAsabi and Gimbî. It was done in Gimbî. The second station consisted Gulisõ, Bõji Chokorsa and Dirmajji, Mana-Sibũ, Najjõ and Jarsõ. It was done in Mana-Sibũ Warada.

Someone who competed to become a parliament member must have two hectares of land or above. He must be a balabat/governor. Gradually, being a member of parliament was focused on the educated ones. The director of Dajjãzmãch Gabra Igzihãbiher School in Gimbî- Ato Bayanã Abdi joined the parliament among the educated ones. Lalo Asabi atibiya dãña were Bayana Yadata, Workina Gõla and Dajjãzmãch Banti Tolasa. Damtõ Mangashã and Banti Tola were the best examples from Yũbdõ Warada. atibiya dãñã was administered by misilane. "Mislene (government agents) to supervise the fulfilment of labor obligation as well as take other punitive measures" [15]. The number of misilane was based on the vastness of that warada. Gimbî Warada had five misilane. These were Dãlõ Sîbã, Lãlõ Colli, Lãlõ Asãbi, Hãru Warra Gib and Warra Annõ. These were led by qaññãzmãch Tafari Ejeta, qaññãzmãch Tafari Tucho, Dajjãzmãch Niguse, Barãnbaras Ababã Dõri and Basha Tasama respectively. Waradãs were administered by misilane whereas the others were administered by mitikil-misilane. Mana-Sibu up until 1953 was administered by mitikil misilane. It was administered under Najjõ- by Gamada Urg ssã. A leader of a misilane administered up to three hundred kalads. Mana-Sibũ was the best example. Misilane structure was cancelled in 1965 and it was changed to waradã. A vast misilane became an independent warada. For example, Lalõ Asabi Misilane became Lãlõ Asãbi Waradã. In other places, two misilane became one warada. Hãru Warra Gibe and Annõ became Hãru Waradã. The number of waradã in Gimbî Awurajjã set up from five to eleven waradãs. The former waradãs were Gimbî, Mana-Sibu,Najjõ, Yũbdõ and Nõle-kãbbã, whereas Bõjji Choqorsa, Dirmaji, LãlõAsãbi ,Jãrsõ, Begi and Hãru were later waradãs. qaññãzmãch -Kãsa Tachãne was the administrator of Gimbî Awurajjã when waradãs increased to eleven waradãs.

Authority/power started from chika shum upwards to atibiya dãñã, misilane, warada administrator and awurajjã administrator. These were the power structure at awurajjã level. The highest power under awurajjã was waradã administrator and awurajjã administrator. The administrators of both waradã and awurajjã were nominated from among the relatives of Kumsã Moroda. Beyond waradã and awurajjã levels, the relative of Kumsã administered mislane level. Tafari Ejeta Rõrõ was the best example of Sîba Misilane administration. Mana-Sibũ Waradã was administered by Dajjãzmãch ChãliYãdata, whereas Barãnbaras Gamadã Urgesa was Najjõ administrator. Tãdase Gamada, Getãchew Chãli,UmarAlkãdir, Azãchaw ch rinat, qaññazmãch Disãsa Kãro were the administrators of Jãrsõ, Bõjji Chokorsa, Yũbdõ, Hãru and Nõle Kãbbã respectively. The Gimbî town administrators were Bãllã Mollã, Adãne and Dajjãzmãch 
Gabre Tsadiq. The above waradã administrative were Kumsã Moroda's relatives. So that, the minstrel said that

\section{Amharic \\ Q}

QWQ

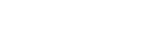

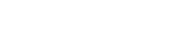

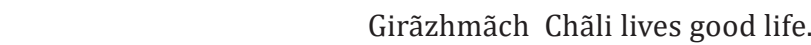

Dajjãzmãch Chãli inherited the waradã administration of other areas. They were under the awurajjã administrator. The Gimbi Awurajja administrators were qaññãzmãch Yamãne Kumsã, Tãdale Mãrkos, qaññãzmãch Kãsã Tachãne, qaññ̃zmãch Hayilu Bera and in 1974 qaññazmãch Hayilu Wadãjo. Since Hailesillassie's political agenda didn't consider the benefit of the majority, different groups of people rose against him.

The Oromõ society could not have full fledged capacity to educate their children [9]. The autocratic rule of Emperor Hailesillassie decided the fate of the society. Due to this, resistance against his autocratic rule took place including student movement, labor strikes, armed struggles \& peasant rebellions. The objective of these oppositions was to overthrow the autocracy and substitute it with another progressive leadership [16]. But when the Emperor was overthrown the military junta came to power. Consequently, the policy of land holding during Emperor Hailesillassie was changed. Under pressures the military proclaimed "land to the tiller." Therefore land became the property of the society at large. No private ownership of land was allowed in the post 1974 revolution. The right of plowing the land and owning it became communal.

\section{Administration of districts in gimbî 1974 to 1991}

The Darg rejected land lords and gave the land to farmers [9]. New administrative structures were put in place in the postHailesillssie's period. That was the Darg's. New political agenda imposed on the Ethiopian society. The land lord, atibiya dãñã, misilane and the like disappeared. However, land after sometime was dominated solely by the government [17].

The government ordered 20 gãshã of land should constitute a kabale. Land was given to the majority (farmers). As Ato Tafara Bultum informed to me that he could not get access to land during Emperor Hailesillassie. He rented plots of land from seven persons. He gave half of the produce to the land lord. When the policy of "land to the tiller" [5] was announced Ato Tafara Bultum was entitled to take all the seven plots of land he had rented. Moreover, the cattle he used to look after was confiscated by him. To explain this situation the community forwarded the following poem:

Oromõ
Abbã lafã yã bukkure

O! the ugly

land lord

Baga Dargîn sisukkũme

It is good

that the Darg has crushed you

Adũn barî bãte galgala ta'ũfi

sun will set in the evening

Garãn guphõ nyãte kalkala ta'ũf

that has been filled with bribes will collapse.

Makînãn dhuferã karã arsîfadhã

Avihecle is come so build the roads

Warri quphõ nyãtan garã barsîfadhã. made corruption a custom be ware.

It means that the superiority of land lords was gone. The Darg focused on farmers. He used the high school and university student to disseminate its ideology in "The Development Through Cooperation Campaign" popularly known as The Zemacha. The university and high school students nominated Shongo in the community. "The zamachã-students transmitted and explained the message of communal farming to the peasant association in West Wallagã" [5]. They taught adult education in Amharic language. Shongõ had high authority at the kabale level. It could punish the criminals charging up to three hundred birr. While civil charge was up to ten birr. Gimbî Waradã Firdi Shongõ was led by Walde Gõsa. A Gimbî Waradã peasant director was Bulchã Andi. The students of the university and the high school established gabare mahibar (farmers Assciation). For example, Bakal ñarõ, Dũressa Gudina, and Lagas Barki were among the high school students in Yũbdõ Warada. There were sixty- three farmers cooperatives in Gimbî Awurajjã (Districts in Gimbî). The Oromõ had 55 cooperative farmers while eight of them were controlled by the Gumuz. They controlled the land of land lord. The land of land lord taken over by cooperative farmers was known as Kudãd [18]. All peasants farmed the land of kudãd jointly. The peasant farmed land using oxen, and axes as a digging instrument. The number of oxen in a given waradã was known during the Darg. Kabale administrator permitted the people to sell their oxen. They punished absentee farmers' fromwork up to ten birr. There was granary in each kabale. The products of cooperative farmers stored in it. Mãyibãsis (storage of grains) was established in 1977 in Districts in Gimbî. The peasants had a share to store their products in mãyibãs by force. Mãyibãsi was established by the contribution of society. They contributed up to eleven birr. The peasants bought farming materials from mãyibãsi. The price of the all materials was fixed by the government. The best examples were Kiltu Kãrrã Mãyibãsi in Mana Sibũ Waradã, Ganji Mãyibãsi in Yũbdõ Waradã and Hõma Mãyibãsi in Gimbî Waradã. All peasants were members.

In 1979, the new government announced a policy against mãyibãsi. It was known as development through cooperative 
association or "development through cooperation campaign zamachã”[9]. The all ruling policy was changed. If development through cooperative association had 60 members, they replaced mãyibãsi and appointed a new shongõ from among themselves. "More than five hundreds peasant association in Gimbî Awurajjã (Districts in Gimbî) have established communal farms, the size, crops and yields"[5]. New ruling policy drafted by them and they received granary, land and properties of mãyibãsi. The members of development through cooperative association (amirachi) cancelled Waradã Mãyibãsi if they had more than six kabales under a given waradã. Hãru Waradã development through cooperative association replaced a former Hãru Mãyibãsi. A new representative was led by Ato Bãbu Gõbanã. The former coffee market mãyibãsi was changed to coffee market. Coffee market was established in every kabales. Coffee market becomes a center of coffee trade up to the 1990s.

Additionally, the Darg brought a unique system of livilihoodMandar Masarata. It was established to administer the peasants. However, the life of the farmers were dismantled. Families were forced to settle on assigned land by leaving their original land, house and other properties. It affected the life of the peasants [19]. According to elders government persuaded peasants by saying that Mandar Masarat was very essential to construct common good: school, electricity, road, clinics, clean water and so on. It was not fulfilled rather it was the way of persuading the farmers. 1981, Mandar Masarata which grew in to municipality were: Gunfi, Bngu'aqiltu jale, tanki, WamaTiba, and so on. Mandar Masarata became a big reason for the dawn fall of the Darg regime. Government began to kept virginity of land by planting trees. The best example was Chuttã forest. Chuttã forest was founded 8km in Chuttã Giyõrgis Kabale. It covered 60 hectares of land. Giyõrgis Kabale, Malkã Bãsi kabale, Gejõ Gale Kabale and Chuttã Sõdu Kabale were its boundaries. It had a long history. Its name came from a widow known as Bõntu Gãcha'o. It was named by Chuttã Bõntu. It served as a place where people worshipped their wãqa. A bad sprit was sent to their properties if they couldn't slaughter cows, sheep and so on. The ruler of that area Bilãta Dheressa kept that forest for a long time. He had $10 \mathrm{l}$ qalad of land and there were a lot of hora which used for medicine in Chuttã forest. These were: hora lemana, sõddu, kotote and so on. Ula Sumbo was one of the strategic places in Chuttã forest. It was a place of worshiping God and irrecha, and a place which used as resting place and so on.

The station of the traders of Lekã,Qelam, Ganji, Gullisõ, Najjõ and the like were there. It also served as a place where the Oromõ used to settle dispute. Bilata Dheressa had exiled during Italian occupation and he returned to Addis Ababa in 1941. Bakare Gobãnã was the relatives of Bilãta Dheresa Amante. His father Amante was killed by an elephant. He died at the place called Sayyõ. Italians buried various commodities in Chuttã forest. They built a house which was $300 \mathrm{~m}$ wide and 230 meters tall. All people feared to check the buried materials in it.
Bilate Dheressa Amante gave Chuttã forest to Kabã Eeba. Kabã Eeba gave it to shumbet Dheressa. The Darg planted eucalyptus and tid highly. Recently, high percent of Chuttã forest is covered by eucalyptus trees.

The government forced the farmers to bring their product to the market especially determining the price for crops like coffee. The policy of Darg tortured the farmers and forced them to revolt against the government. Eventually, different forces were organized to get rid of the brutal Darg regime. These were: EPLF, TPLF, OLF and others.

The upper echelons of the Darg established their own party known as Peoples Democratic Republic of Ethiopia. The peasants who supported the OLF around Wallagã were murdered. This armed group highly struggled against the Darg's rule [20]. This thesis tries to highlight a history OLF in Districts in Gimbî in the following discussion.

The struggle of the Oromõ Liberation Front started without unity. Their intention was to defeat the brutal force of Hailesillassie. The emperor could not treat all citizens equally. One group was beneficiaries while other were losers. As Gadã Malbã explains Tadasa Birũ was one among the highest echelons. The authorized body consulted to discuss the education of Ethiopia. Their discussion was based on the Oromõ society. The Oromõ had vast land and people. So, it might be a headache for us if we gave them education. So, to neglect the Oromõ was the best alternative. Tãdasa Birũ was a number of that meeting. They assumed Tãdasa as an Amãra. But, Tãdasa was from the Oromõ ethnic entity. The program was to deny the right of education to the Oromo. Suddenly, Tãdasa Birũ consulted with one who was proud of his Oromummã (being an Oromõ): Mãmõ Muzamir, Hayile Mãriyam Gamada and Ali Cirri. They underlined to start struggle against the emperor. Tãdasa Birũ gave a chance of education to the Oromõ. A group of selected society tried their best to create awareness in the society using singers. In case of Districts in Gimbî, Burka Bõjjî, Bikiltũ Mandi and Lalisa Najjõ were the peculiar ones [21]. "It was decided the next culture festival in 1977 at Enangõ, Gimbî Provinces next to [the] 1976 [held] at Bokku Tulle" [9]. They began to defy Emperor Hailesillassie. The defeat of Emperor Hayile Silase couldn't bring a bright light to the Oromõ. The total percentage of the Oromõ participants in the central committee was small. The numbers of the Oromõ who were in administrative position were only 23 out of 200 [9]. Again, the Oromõ started wrestling with the brutal force of the Darg. The news paper barîsã which published the history of the Oromõ later on was neglected by the government [9]. MandarMasarat was a method of societal separate from the Oromõ Liberation Front. The Darg used it as one system. Hararge, Bale, Arsi and Sidãmõ were the stepping stone of the resistance of the Oromõ Liberation Front. Gradually, during the period of the Darg the OLF expanded to Wallagã in general and the Districts in Gimbî in particular. The leaders of this movement under Districts in Gimbî were Galãsa Dilbõ (who 
served as a central committee for the Oromõ Liberation Front), Dawud Ibsã and Dima Nagawõ and so on. The strong army of the Darg stationed in Gimbî Awurajjã (Districts in Gimbî) to control the force of the Oromõ Liberation Front were led by Shalaka Alakã kabade who was a commander of the Darg soldier in Begi kabale. The political agenda of the Darg was run by Shalakã Alaka Tãdase. Twenty eight kifle tori was the contingent of the Darg in Districts in Gimbî. The two opposite parties brought big shock in Districts in Gimbî.

The training stations as well as campaign of these parties became abundant in Districts in Gimbî. They had different camps both in Asõsa and Districts in Gimbî. Their big camps were: Kasar, Tasha, Bãnga and Yãbus. The small camps were tõre, Tarko, Weste Wadssa, Odã Gõdar, Gumã, Walalã, and so on. The biggest camp and jail existed in the Sudan at Bokore. The places of war were: B gi, Ya'a Masara, Gidãmi, Mana-Sibũ, Kobor, Sirbã Abayã, Odã Gõdar, Babõ Gambel, Tullu Walal and Giddã. These areas were named yatõri katana (area of war). All these camps were constructed under the ground. A ditch was constructed for not more than six soldieries. Their war materials were also stored under the ground. The organizers of the Oromõ Liberation Front around these areas were: Yõhãnnis Latã, Dawid Ibsã, L nchõ Latã, Korme Abbã Chãlã Latã, and Milk sa Lata. Milk ssa Latã served as a central committee over Districts in Gimbî.

The outside force was the supporter of the Oromõ Liberation Fronts. Sudan opposed the Darg. Because, the Darg supported the Sudan Liberation Front. Apparently, the United States of America and Germany gave war materials to the Oromõ Liberation Front. The reason was that the Darg rejected capitalist ideology. The Oromõ war materials: M4, M1 and different cars were the gift of the United States of America. The government of the Sudan initiated the Oromõ Liberation Front establishing Radio Broadcast in the Sudan. This part announced their objectives to the world stage from the Sudan [22].

The methods of their resistances against the Darg were of two kinds. These were guerilla fighting and conventional. The Oromõ Liberation Front always prepared to struggle through guerrilla fighting. Kesar, Tashã, Assõsa, BãngaYãbus, Shigaso and $B$ gi were places where the two parties faught face to face. Karut and Sõni were the facilitators of thesoldiers of OLF. Sõni was a soldier like bee and used for information gathering before the soldiers went out from the camp. Sõni was known as a facilitator or information gatherer. Karut was somewhat different from Sõni. Its duties were also different from Sõni. He commands the army in a given mission. He informed them checking atomic bomb and other war materials under the ground. Karut was a leader of the soldiers. The soldiers of the Oromõ Liberation Front had its own structure. As an example, the 1st structure was a group of three persons and a leader. Their power divisions was as fellows. A leader of three persons was one murasa. And it continued as such.
Saglî(3) a leader of three persons

$\downarrow$

Murãsa (1)

Murãssi (3

$\downarrow$

Buttã(1)

Buttãn (3)

$\downarrow$

Chibra (1)

Chibri (3)

$\downarrow$

Birg di (1)

Birg di (3)

$\downarrow$

Kutã warãna (1) a leaders of the soldiers.

Kuta Warãna was a commander or the leader of the army. He could order, guide, plan and command the soldiers. Majorities of the soldiers of the Oromõ Liberation Front were from the Oromõ whereas minorities were from the others. A small number of the members was from Assõsa, B nishãngul and Sudan [22]. "Majority of the Oromõ people have accepted the Oromõ Liberation Front as their organization"[20]. The Oromõ used different tactics to bring members to their party. The first method was to use force. They traveled to different areas to capture a new face. Their targets were schools, churches, mosques and markets. They captured new members by force from Churches, mosques, markets and schools. They couldn't consider about the age and sex. They captured together and took them to their camps. The family waited for the coming of their children from the schools. Nevertheless, they were taken to somewhere else. The other method they used to capture other members was demonstrating sport in markets. They demonstrated sports in a market more than two or three times. On the 3rd or the 4 th round, when many youngsters came to watch sports, they captured them and took them to their camp. Sometimes, they captured a person going to individual's house. They usually went at night time. Since they terrified the peasants, no one could refuse them. The Darg demonstrated brutal force to the farmers. The one who ask question among the peasant lost their life. When the children became orphan the Oromõ Liberation Front took them and trained them in military science. The military of the Oromõ Liberation Front below fourteen years were known by q ransõ. They trained in camp up until fourteen years. The military beyond fourteen years were called jajab. Jajab was hope-full military. Its nick-name was warãna lafõ (foot soldiers). They could attack enemy without war materials. 
The activities of the oromõ Liberation Front was not only capturing new members but also robbed property like war materials, grains, and the like. The peasants also fed them unwillingly. Because of this, peasants feared them a lot. Politics and military train were the points given to the members. Their political education focused on tactics used to overcome the brutal force of the Darg. This implies that they educated as this party is running class struggle. There might be scarcity of food in class struggle. So, they taught as they eat monkey, python, snakes, bush buck, and as their economy depend on the Oromõ society. They taught that one bullet must be reserved for the fighter, because instead of being captured by enemy, the best alternative was to kill oneself.

The brutal force of the Darg's regime defeated by the mushroomed parties in different parts of the country. These parties were: Tigray Liberation Front, Oromõ Liberation Front and the like. The revolts of these parties led to the complete collapse of the Darg regime and the coming of the EPRDF to power in 1991 [16].

\section{Conclusion}

The heavy hand of the emperor Menilik, Haile silassie and the Darg exacerbated the people of the Ethiopians. The policy that they applied on the people was not far apart from each other. Emperor menilik forcefully impoverished people and brought them under his rule. Not only him Emperior Haile silasie damped the people of the Ethiopia in general and Gimbi districts (Mandi, Nole Kaba, Yubdo,Gimbi and Najo) in particular. The policy of emperor Hailesilasie paralyzed the societies of the Gimbi district appointing abba koro, misilane, warada administrative and zonal administrative. They forcefully collect money from the people and deposited to the central government. The joint force of many parts in Ethiopia dethrone haile silasie and throne the Dergs regime. The qudad land of the emperior Haile silasie has been taken by the Derg. The brutal force of the Derg put the people in the ring by the name of manadare masarata, communalism, zemecha and so on. The brutal force of the Darg came under quotation in Gimbi Districts by OLF structure karute, soni and jajabe forces as well as the wonderful structure they used like sagli, murasa, cibra, birgedi and kuta warana.

\section{References}

1. Giday D (2006) Traditional Mechanism of conflict resolution in Ethiopia. (ed.), AA: ELLPP.

2. Tesema T (1980) The Oromo of wollega: A historical survey to 1910. AA: AAU.

3. Bula S (2000) A history of seventh day Adventist in Ghimbi 1925-1928 BA. thesis, AA: AAU.
4. Lemessa M (2014) Indigenous forest management among the Oromo of HorroGuduru, Western Ethiopia. Ethiop. j. soc. lang. stud 1(2): 5-22.

5. Stahl M (1997) New seeds in old soil: a study of the land refiorm process in west Wollega Ethiopian 1975-76, Uppsala: Scandinavian Institute of African S studies.

6. Lemesa G (1987) The impacts of the 1974 Ethiopian revolution on local government, B.A theiss, AA: AAU.

7. Aren G (1999) Envoys of the gospel in Ethiopia in the steps of the evangelical pioneers 1898-1936. Gusav Aren and verbun publisher, Stockholm, Sweden.

8. Legese L (1979) Political economic of Ethiopia 1875-1974: agricultura, educational and international antecedents of the evolution, ph.d dissertation. Nordame: India.

9. Gada M (1988) Oromia: an introduction to history. Khartoum, Sudan.

10. Terefe W (1968) "The unification of Ethiopia (1880-1935) wallaga”, in journal of Ethiopian Studies. 6(1) AA: AAU Press.

11. Gutema I (1987) A historical survey of land tenure system in Aira Gulliso woreda central wallaga 1889 to 1935 . AA: AAU.

12. Pankhrust R (1966) State and land in Ethiopia. AA: AAU.

13. Nagaso G etal (1972) "The introduction and expansion of Orthodox Christianity in Qalem Awuraja western wellega, from about 1886 o 1941," in journal of Ethiopia studies. 10(1) AA: AAU.

14. Muluqan W (1995) Seena hundefamaa fi gudina mgaala gimbi hanga bara 1991.

15. Negusey A (1982) The Ethiopia revolution: political aspects of the revolution from PMAC to PDRE," in Marina ohaway, (ed.), in the political economy of Ethiopia. Nardiska African Institute Uppsala, Sweden.

16. Bahru Z (2002) Modern history of Ethiopia 1855 1991. AA: AAU.

17. Dessalegn R (1994) "Agrarian change and agrarian crisis: state and peasantry post revolutionary Ethiopia," in Harnold G. Marcus et al., (ed.), in paper of the $12^{\text {th }}$ international conference of Ethiopian Studies, Michignan state University 5-10 September 1994, Lawrence ville: Red Sea Press, USA.

18. Tesema T (1984) "The basis for the political contradictions in wollega. The land appointments act of 1910 and its consequences, in North East African Studies. 6(1-2).

19. Alemayew L (1989) Villagization and agricultural production in Ethiopia: a case study of two regions IDR research report prepared for the win rock international institute for agricultural development. AA: AAU Press.

20. Asefa J (1997) "Oromo nationalism in the new global context". Journal of Oromo studies, University of Tennessee, USA. 4(1-2).

21. Gadaa M (1985)

22. Mohamed H (2000) "A history of Oromo colonial experience: part two colonial consolidation and resistance 1935-2000". in Journal of Oromo studies, University of Tennessee, USA. 7(1-2). 
(C) This work is licensed under Creative Commons Attribution 4.0 Licens
Your next submission with Juniper Publishers will reach you the below assets

- Quality Editorial service

- Swift Peer Review

- Reprints availability

- E-prints Service

- Manuscript Podcast for convenient understanding

- Global attainment for your research

- Manuscript accessibility in different formats ( Pdf, E-pub, Full Text, Audio)

- Unceasing customer service

Track the below URL for one-step submission https://juniperpublishers.com/online-submission.php 